Revising rationality: the use of 'Nudge' approaches in neoliberal education policy

Alice Bradbury, Ian McGimpsey and Diego Santori

University of Roehampton, London, UK; Institute of Education, University of London, $U K$; Institute of Education, University of London, UK 


\title{
Revising rationality: the use of 'Nudge' approaches in neoliberal education policy
}

\begin{abstract}
This article argues that the concept of rationality is undergoing significant revision in UK education policy making, influenced by developments in several academic fields. This article focuses on the take up of behavioural economics in policy as one aspect of this revision of the concept of rationality, discussing how this has happened and its implications. Framed by a wider debate regarding the significance of a 'crisis' in neoliberal approaches to social change, behavioural economics suggests that a reliance on rational choice is insufficient and individuals need to be 'nudged' to make good choices. This revision and its impact on the subject of policy, the policy maker and policy technologies are examined, and the discussion is supported by two illustrations from school choice and youth service policy texts from the 2000s. The potential use of 'nudge' theory in education is also considered with respect to the ConservativeLiberal Democrat government's use of behavioural economics. In conclusion, we argue that the use of these ideas in policy, alongside others, marks a revision of the neoliberal idea of a rational chooser as the aim of policy making, of which education policy sociology should take account.
\end{abstract}

Keywords: rationality; neoliberalism; behavioural economics; school choice; choice advisers; youth work

\section{Introduction}

In 2010 the UK Prime Minister David Cameron set up the Behavioural Insights Team, a specialist unit within the Cabinet Office to promote the use of behavioural economics in policy making across government (Cabinet Office, 2011). This team is commonly referred to as the 'Nudge Unit' (Wintour, 2010), after the 2008 book by Richard Thaler and Cass Sunstein which popularised theories of behavioural economics and discussed their potential application in policy. Nudge theory, in a nutshell, suggests that individuals do not always make the choices that would benefit them most, that failures to choose well are the result of common cognitive flaws or limitations and are thus predictable, and that therefore everyday decision-making can and should be framed in particular ways to encourage ('nudge') people to choose in advantageous ways. This idea recasts the design of large scale systems (such as savings, health care, and education) as 'choice architectures', designed for the production of optimum outcomes (from the perspective of the system designer) without removing freedom of choice from the individual. Although there have been doubts raised about the effectiveness of this theory in policy making (Chakrabortty, 2010; Curtis, 2011; Tyler, 2011), the prominence being enjoyed by behavioural economics within the UK Coalition 
government is significant, and, we argue, can be seen as evidence of a wider revision of the idea of the rational, choosing subject within policy.

In the UK there is a significant revision under way, we argue, of the rational neoliberal subject which has been figured in policy during the last three decades, a revision which is in part resourced by the contingent knowledge of behavioural economics. This use of Nudge theory (which is explained in further detail below) and the attendant revision of the rational subject in policy should, we suggest, be considered within the context of discussion of a 'crisis' in neoliberalism following the global financial crisis of 2008 (Gamble, 2010). However, though the language of crisis might be taken to signify a significant discontinuity with neoliberal policy-making since the 1980s, these shifts in policy away from a 'pure' vision of the rationally choosing consumer-subject are, in our view, as yet only revisions of neoliberalism and not a larger disruption (c.f. Jones, 2010). Significantly, the idealisation of individual choice within policy remains, even while individuals' ability to correctly deploy that choice is criticised. In this article, we use illustrations from school choice policy and youth services to examine how these revisions operate to reconfigure the rational subject within policy texts, and some of the effects it may have in doing so. Specifically, we explore how the revision of the subject of policy implies a revision of the subject of policy making.

It should be noted that Nudge theory does not stand alone as such an influence on recent policy: the utilisation of neuroscience and network theory can also be seen as evidence of revision to the conception of rational subjects in policy. However, considered as aspects of this revision, each has its own specificity. This change is characterised not by a linear movement to an alternative ideal human rationality, but rather by contingency. Multiple moves are made in the face of different policy problems, utilising different conceptions of the subject of policy that draw on several contingent knowledges. Thus, the revision of rationality taking place is not a move to a changed yet singular notion of the rational subject but rather it describes a changing field of possibilities allowing different discursive moves to be made in the context of policy production. Similarly, it is not a move from a singular neoliberal rational subject, as we discuss further below. 
This is a complex, inconsistent and still developing picture. As such, it is our argument that a depiction of this changing field of discursive possibility in policy is best served through discussion of each of these aspects in a way which allows for the specificity of their influence. That is, it is not that there is such complexity that the revision of rationality cannot be characterised, but rather that because of the discontinuity of each of its aspects, such a characterisation is best built up from an account of each. This article is therefore a deliberately limited contribution, in that rather than attempt to deal with each aspect of the revision in a single article, we focus here on behavioural economics, and use this as a basis for critical discussion of some of the implications of this revision. We do this with the intention of developing similarly specific accounts of the particular influence of other aspects, in the belief that this will ultimately provide a more satisfactory discussion.

\section{Neoliberalism, policy reform, and the subjects of policy}

Neoliberalism has been a central feature of education reforms pursued in the UK by successive governments since the 1980s, and by policy makers in other countries around the world as a part of processes of transnational 'policy borrowing' (Green, 1993). This article seeks to contribute to efforts to 'document the processes and effects of the various and sometimes contradictory elements' (Apple, 2001, p. 66) of these reforms, through a discussion of a specific, and indeed contradictory, development within neoliberal policy making that has occurred in the last five years. Before doing so, it is worth briefly discussing our understanding of neoliberalism and particularly the aspects of the term we focus on in this piece of policy analysis.

Over the course of the last 30 years, policy makers of successive governments have pursued the introduction of market mechanisms in the supply of public services in response to the twin national policy imperatives of efficiency and effectiveness, in turn driven by competitive pressures associated with a globalised economy (Ball, 2008b, pp. 14-25; Le Grand, 2001; Levin and Belfield, 2003, p. 624). In contrast to classical liberalism's requirement of market freedom from the state, the 'quasi-markets' established as a part of these neoliberal reforms have tended to feature significant state regulation and intervention (Le Grand, 2001; West and Pennell, 2002; Whitty, 1997), even as the policy discourse has often spoken of devolution and autonomy. The neoliberal state is figured as the ally of the market 'by providing conditions, laws and institutions necessary for its operation' (Olssen, 1996, p. 340). As Apple puts it, it has 
been 'odd combination[s] of marketized individualism and control' (Apple, 2003, p. 10) that have allowed the market to operate - for example, national testing from a common curriculum underpinned a system of state school performance assessment which comprised an information base from which parents, refigured as consumers of education services, could choose which school was the preferred provider to their children (Bowe, Ball and Gold, 1992).

For a market to function, certain assumptions must hold true about transactors, namely that buyers are knowledgeable actors seeking to optimise the utility of supplied goods in relation to their expenditure, and that sellers are seeking to optimise their profits (Levin and Belfield, 2003, p. 623). That is, both buyers and sellers are 'rational' in the sense of being individuals primarily interested in cost minimisation and utility maximisation and who will act on the basis of these motivations, and informed in the sense of possessing the knowledge of the self and of products and services made available within the market on which to base choices. However, scholars exploring the distinctive nature and effects of neoliberal policy-making have made the argument that just as neoliberalism entails a particular relation of the market and the state, the term equally entails specific subjectivities, and a specific productive relation of the market and subjects.

The neoliberal subject is an entrepreneurial individual; the active agent of their own self-interest within a competitive world. They are a subject that can capitalise on 'an apparently equal chance to utilise their powers of consumer choice and control' (Vincent, 1994, p. 263) in pursuit of their own individual interests. Whereas classical liberalism sought to reveal this rational actor by freeing them, as Olssen points out, neoliberalism is characterised by the concern that in 'an age of universal welfare...[that creates] perceived possibilities of slothful indolence' (Olssen, 1996, p. 340) subjects must be made to be rational. Hence, an important theme of educational policy sociology particularly since the early 1990s has been the marketisation of institutions as a means of the production of 'rational' subjectivities, and, as a corollary, ethical questions of the effects of these productions. Notably, Ball has characterised the market as a 'policy technology' implicated in these productions, alongside the associated technologies of managerialism and performativity (Ball, 2003, p. 215). Through these techniques, a combination of choice, competition and compliance become the means of the production of the 'neoliberal subject' (Walkerdine, 2003) in a market-state. Rather than 
being liberated to act rationally, 'rational' subjects are constituted in a game of incentives and threats (Ball, 2001; Ball, 2003).

Our argument is this: first, that within the neoliberal regime a new knowledge of the subject is being constituted, one that is of the limited effectiveness of neoliberal policy technologies in constituting subjects as rational. Second, that this revised subject of rationality implies a change in the game, a change in the ends and the means of the governance of the subject within the neoliberal regime. Third, that this 'discontinuity' in the terms of neoliberal discourse is not an end of neoliberalism, but, even amidst all the discussion of a 'crisis' of neoliberalism, is necessary precisely to ensure a continuity of the neoliberal regime.

\section{Crisis and continuity: the co-option of behavioural economics}

Following the global financial crash of 2008, several scholars announced a 'crisis' of neoliberalism (Duménil and Lévy, 2011), its end (Birch and Mykhnenko, 2010), and subsequently its survival (Crouch, 2011). Since then, the problems of the global financial system, and its impact on the economies of major Western economies has been a staple of mainstream political discourse in the UK. In the same year in which it became not only possible but seemingly necessary for policy makers to discuss the limits, the weaknesses and the problems of global capitalism, Thaler and Sunstein published their book Nudge: Improving decisions about health, wealth and happiness (2008), a guide to the application of behavioural economics in policy.

As probably the most prominent of several popular texts on a similar topic, the book describes behavioural economics as a field that combines psychological, social and economic research to arrive at the foundational proposition that there are inherent limitations on individuals' capacity for rationality. Put simply, a behavioural economist is likely to suggest that people are not as rational as they are often assumed to be in policy. Further, retaining the methodological individualism of economics, the irrationality individuals possess becomes the attributed cause of major social and economic problems (from obesity, poverty in retirement and, in the book's second edition, over-indebtedness the banking system) as a range of systems produce less than optimal outcomes. The project of behavioural economics, then, is to model the essential irrationality of choosers, and in so doing to render the flaws in their choosing 
predictable (Thaler and Sunstein, 2009). This new knowledge of the predictably irrational subject can then be used to make claims as to how social and economic systems might be designed to counteract individuals' tendencies to make 'bad' decisions and to stimulate 'good' decisions.

Behavioural economics locates this irrationality both i) in the human brain, and therefore as an inevitable part of the cognition of all subjects, and ii) alongside rationality which is also located in the human brain. In Nudge, Thaler and Sunstein contrast two models of individual rationality: 'Econs', based on a rational subject, and 'Humans', who are real people:

If you look at economic textbooks, you will learn that homo economicus can think like Albert Einstein, store as much memory as IBM's Big Blue, and exercise the will power of Mahatma Gandhi. Really. But the folks that we know are not like that. Real people have trouble with long division if they don't have a calculator, sometimes forget their spouse's birthday, and have a hangover on New Year's Day (Thaler and Sunstein, 2009, p. 7).

While, in Thaler and Sunstein's account, neoclassical economics assumed an ideal rational subject, behavioural economics uses these two figures of the Human and the Econ to represent people's choosing behaviours as one of two types associated with two 'types of thinking' our brains perform (Thaler and Sunstein, 2009, pp. 7-9; 21-24). The first one is produced by the brain's Automatic System, which is rapid, emotional and instinctive, and the second by the Reflective System, which is more deliberate and self-conscious.

These systems are used to produce a conception of the operation of the individual actor which is embedded within an understanding of economics that argues that while individuals may try to maximise their personal advantage, in our everyday life the decisions we make do not reflect a 'pure' rationality. More specifically, such an analysis of rationality can be used to argue that neoclassical economics is powerful in explaining immediate and relatively simple decision-making - e.g. a person comparing price and quality when buying a product - but has too little to say about the evolution over time of larger economic systems (Dawnay and Shah, 2005, p. 3). Such longer-term trends, it is suggested, are best seen not as simply the result of an accumulation of shortterm 'rational' choices, but also as the result of biases inherent in subjects' decision making produced by automatic systems of cognition: e.g. social influences on our preferences; the inability to think through the implications of complex or long-term decisions making where we receive limited feedback; the tendency to be over-cautious 
with respect to the pain of loss when judging risk; and the deferral of unpleasant tasks such as navigating bureaucratic processes (Dawnay and Shah, 2005; Dolan et al, 2010; Thaler and Sunstein, 2009).

Crucially, at a time of major systemic disruption behavioural economics was not only a knowledge that was contingent to policy contexts, but one that was actively utilised in order to name and to solve policy problems that presented themselves at this time. That is to say, the alternative conceptualisation of rationality within behavioural economics began to be articulated by policy makers as a means of facing some of the problems that seemed to be thrown up by the financial crisis. In the immediate aftermath of the crash, behavioural economics offered itself as an explanation both of a lack of foresight, and, at root, how the problem occurred (Thaler and Sunstein, 2009, pp. 255260). Further, in a context of constrained public spending, behavioural economics has been positioned as part of the approach to making ends meet (Cabinet Office, 2011).

This discourse has been taken up within the context of policy making in the UK in several ways. The introduction of the so-called 'Nudge Unit' within the Cabinet Office by the Coalition government is perhaps the most prominent example of an attempt to develop new policy technologies from the knowledge of the subjects of policy offered by 'behavioural sciences'[1]. The Department for Education also currently fund the Centre for Understanding Behaviour Change (CUBeC). One of three research centres the DfE fund at the time of writing, it cites behavioural economics and Nudge as influential in its efforts to 'understand how to promote desired behavioural changes amongst young people' (Burgess, 2012). Meanwhile, think-tanks that held influential positions in policy networks produced a series of reports that essentially did a job of translation and prompting discussion; for example, the Institute for Government (Dolan et al, 2010), the New Economics Foundation (Dawnay and Shah, 2005) and the RSA (Rowson, 2011) have released reports discussing the applications of behavioural economics and the 'behavioural sciences', with utilisation in policy a key theme. In this way, behavioural economics has come to allow for the articulation of 'new' approaches to policy making through which to pursue (largely unchanged) political goals. These new approaches are revisions, then; not revolutions but evolutions of policy discourses that maintain the market form in social structures while compensating for the shortfalls of neoclassical economic theory. 


\section{Changing the game [2]: Choice architecture and Libertarian Paternalism}

There are significant implications of this economic approach for policy-making. Behavioural economics envisages a different subject of policy and a different policymaking subject than neoclassical economics. In rejecting the idea that 'almost all people, almost all of the time, make choices that are in their best interest or at the very least are better than the choices that would be made by someone else' (Thaler and Sunstein, 2009, p. 10), Nudge recuperates, or perhaps more accurately, reinvents the value and the nature of the intervention of the state in an approach to policy they call 'libertarian paternalism'.

Libertarian paternalism describes a political philosophy in which the freedoms offered by the market to make agentic choices on the basis of rational individual selfinterest are maintained, while at the same time the social and economic systems in which people make choices are conditioned and regulated so as to protect the individual, and by extension the state, from their own choosing behaviours. This is a 'soft...nonintrusive type of paternalism' (Thaler and Sunstein, 2009, p. 6), that will not force subjects to consume, behave, spend or save in any particular way, but will 'nudge' them towards 'better' choices.

The notion of liberal paternalism logically requires two things. First, that decisions be made centrally about what outcomes are desirable, and the nature of decisions that would be made by the rational individual to achieve those outcomes. Second, that a system designer or the 'choice architect' (Thaler and Sunstein, 2009, pp. 12-14) who, utilising their knowledge of the individual, can put in place measures to produce the desired outcomes knowing the patterns of irrationality subjects are likely to produce in their choosing behaviours. Such measures are often referred to as 'nudges' (Tyler, 2011; Wintour, 2010).

In this conception of 'choice architecture' we can see the contradictory nature of the re-figuring of both the subject of policy, and the policy making subject. The policy maker is constructed as inevitably a choice architect, inescapably implicated by the new knowledge of the effects of system design on individuals' choices. Within this discourse, the ineluctable conclusion is that there can no longer be any such thing as 'neutral' design (Thaler and Sunstein, 2009, p. 3). Every feature of the environment has its effects on behaviour, intended by the designer or not, and therefore one should consciously construct the environment in a way that brings greater benefit to the users 
and the wider social system. The strategies for 'nudging' are too many to list here; however, for example Nudge (Thaler and Sunstein, 2009) argues that policy makers should design systems that provide sensible defaults. That is to say, the selection of a particular option judged to be optimal for most people is assumed except when another choice is explicitly made by an individual. In the example of default options and all other 'nudges', the intention is to work with, or to make allowance for, the predictable failings of the subject to be 'rational'.

Further, the changed understanding of the subject results in a shift in the site of policy production from the subject to the choices they make. Precisely to the extent that the subject is understood to contain an inherent and essential irrationality in their 'inbuilt responses to the world' (Dolan et al, 2010, p. 8), the production of a fully 'rational' subject becomes impossible. The effort of production is centred, then, not on an internalisation of rationality but on an externalisation of 'choice'. That is to say, this is an approach based not on changing individuals, but "on "changing contexts" - the environment within which we make decisions and respond to cues' (Dolan et al, 2010, p. 8), in order to 'influence' behaviour. The crucial point here is that 'liberal paternalism' thus implies a change in the game. The goal is no longer the production (in neoliberal terms) of appropriately 'rational' subjects through technologies of managerialism, markets and performativity, but rather 'rational' choices.

However, it is important to note that we are by no means claiming that there is taking place some kind of epochal shift away from the rational subject within policy, and thus away from liberalism. 'Liberal paternalism' has not supplanted or replaced neoliberal policy making. In fact, it is key to understanding the nature and operation of 'nudge' that it does not do so. This is not a radical discontinuity in the goals and modalities of neoliberal policy making. Rather our claim is, in a sense, precisely the reverse. This is a refinement of a technocratic technique, a means of the efficient production of outcomes, a route to greater systemic efficiency. It is a subtle adjustment, a revision of the conception of the subject which is nonetheless significant for at least two reasons. The first is that it is significant not because of its discontinuity with the past, but because of the continuities it makes for in late capitalist societies despite the spectacular, and at the time of writing continuing, systemic disruptions following with the financial crash of 2008. The irony is that this revision which is the incorporation of a knowledge of the irrationality of the subject into the rational subject (such that the 
two co-exist in the same subject) is necessary for the continuation of the dominant market form in social and economic life. It is true that the shift from the internal life of the subject to their behaviours as the site of regulated production is only possible with the development of new policy technologies. However, it is significant that even within efforts to develop and promote these new technological developments, there is continual evidence of the value placed on not disrupting or displacing neoliberal policy technologies, but to work harmoniously with them, to supplement, to incorporate, and in doing so enhance the effectiveness of existing policy-making. As the Mindspace report, commissioned by the Cabinet Office, states:

[This approach] builds on existing methods of policy making...In basic terms, Mindspace represents the tools for changing behaviour...but...it should not simply be seen as an alternative to existing methods. "Behaviour Change" is part of policymaking, rather than a novel alternative that can be bolted onto policies. (Dolan et al, 2010, p. 9)

The revision of the subject of policy is further significant because, we argue, it makes for a revision of the policy making subject; in incorporating and valorising a new knowledge of the subjects of policy, and making available new policy technologies with which to pursue political ends, it recasts their proper role. The policy-making subject is a subject of a new knowledge, a knowledge of the impact of environment on behaviour. The policy-making subject is being changed by their knowledge of others (the subjects of policy); by an ineluctable logic, policy-makers' knowledge of the susceptibility of subjects of policy to predictable influence of their environment (the result of their 'irrationality') is a re-making of the policy-maker themselves. They become an architect, indeed a 'choice architect' (Thaler and Sunstein, 2009, pp. 12-14), a designer of contexts that are not neutral but are determinants of the choices subjects of policy make. Indeed, the logic of the reform of the policy maker is ineluctable precisely because there is no longer any possibility of 'neutrality' to their actions, a 'neutrality' that had been allowed by the rationality of the individual choosing subject. Within the terms of this behaviourist/policy discourse, a policy maker that provides mechanisms for making choices and ensures access to information with which to make choices, cannot but be aware that the choices made will be affected by the way in which the mechanism is designed, how information is presented, if and how feedback on prior choices is given, who presents information, and so on. By knowing these effects, the policy maker has already become a figure that influences choosing over and above individual's 'rational' assessment of their interests. Though of course, the policy-maker 
simultaneously determines (via environmental design) and does not determine, always leaving open the possibility of individuals' alternative choices should they make them, even when those choices are 'bad'. They key point is that policy-makers are in this way set in a new relationship with subjects of policy. Further, this changed relation of these reconstituted subjects of policy and policy-maker subjects necessarily implies a change in power relations (Foucault, 1981, pp. 92-96). It is part of our hope in making this argument that it might be more possible for future critical sociological work to understand the social justice effects of such a change in power relations.

However, having made a claim to the importance of these changes, we should clearly say that we further accept that such a movement is not necessarily in one direction in a consistent fashion; it has many elements working at different speeds and in different sites. We do not wish to overstate the homogeneity or coherence of neoliberal policy discourse and thus to over-simplify. There are active resistances to liberal paternalism within policy contexts that may yet be successful, and it is an open question whether 'nudging' will be able to establish itself as an 'effective' set of strategies for neoliberal policy makers (Curtis, 2011; Tyler, 2011). Nevertheless, this shift marks an important change, at least potentially, in the understanding within policy of who the subject 'is' and what policy can 'do' to them.

\section{The 'long crisis' of neoliberalism}

The 2008 economic crisis made spectacular some of the weaknesses and problems of the neoliberal regime. We have noted here that behaviour change, and the behavioural sciences came to enjoy greater prominence in UK policy discourse at the time of the financial crash and its immediate aftermath, and have speculated that its take-up in these discourses may have been in some sense a process of making use of contingent knowledges in order to produce credible explanations for policy problems, and new technologies for their solution. However, while it may be the case that this was the moment in which weaknesses were made visible such that they had to be talked about, we would argue that these weaknesses were present prior to 2008 as evidenced by policy responses to them, even while the terms of the current discourse were not in use. That is to say, our suggestion is that there were underlying weaknesses in the neoliberal policy regime which the economic crisis of the late 2000s made evident.

Furthermore, the solidity and coherence of neoliberalism in general should not be overstated. Neoliberal policy over the past four decades has demonstrated its 
'transformative and adaptive capacity' (Peck and Tickell, 2002, p. 380). The workings of this 'malleable technology' (Ong, 2006) have been captured in multiple ways, including Jessop's notion of the 'Competition State' - a state which 'prioritizes the pursuit of strategies intended to create, restructure or reinforce (...) the competitive advantages of its territory, population, built environment, social institutions and economic agents' (Jessop, 2002, p. 96); and Rose's conceptualization of 'advanced liberalism', which accounts for the techniques of governments 'that create a distance between the decisions of formal political institutions and other social actors, conceive of these actors in new ways as subjects of responsibility, autonomy and choice, and seek to act upon them through shaping and utilizing their freedom' (Rose, 1996, pp. 5354). Within the UK education context, Ball's account of the 'continuities' between Thatcher's free-market agenda and Blair's Third Way Politics evidences the plasticity of education neoliberal policy (Ball, 2007). The latter's market model of governance could be considered an iterative development that "[repositioned] the state as a commissioner and monitor of the public services [...] rather than deliverer or even owner and funder' (Ball, 2007, p. 5).

Our argument of the co-option of behavioural economics for the continuity of the neoliberal project builds on these accounts. Thus we acknowledge the continuities that have ensured the sustained dominance of neoliberalism as a strategy for governance, and also argue that the incorporation of behavioural economics is distinct in its reliance on a significant revision of the subject of policy. This iteration of neoliberal policy requires a 'revision of the anthropologic assumptions underpinning the political and ethical liberal project: the rationality of our actions and the ethical implications that arise from them.

We argue that discourses of behavioural sciences were taken up at the point at which it became necessary for policy makers to represent reformations of neoliberal policy making, following the financial crisis of 2008. However, we begin our policy analysis several years prior to this, and we seek to demonstrate through two illustrations of specific education policies the development of policy technologies that are made possible by, or at least imply, incorporations of essentially behaviourist conceptions of the subject into neoliberal policy ensembles at this earlier time. This analysis of policy texts does not provide the basis for, and we do not attempt, a wider discussion of the effects of these policies in addressing either their stated purposes, nor wider questions 
of social justice. Questions of the desirability of these policies warrant a dedicated discussion, which we hope this article might serve to open up. However, these illustrations act, we suggest, as evidence of underlying problems faced by policy makers in a neoliberal regime. We subsequently seek then to show the continuities of the particular policy moves with the post-crash period in which behavioural sciences have been more clearly incorporated into the discourse.

\section{Revised rationality: school choice advisers}

The most prominent example of neoliberal policy in education in the UK relates to school choice; however, we argue that even within this policy, there have been developments which represent implicit shifts in government thinking about rationality. The expansion of parental choice following the 1988 Education Reform Act epitomised for many the incorporation of neoliberalism into education. A system of 'open enrolment' allowed parents to choose where their children went to primary and secondary school, while Local Authorities lost the right to limit admissions, and the financial management of budgets was handed over to schools. The publication of assessment results was introduced to empower parents in this choice, by providing, in theory at least, evidence of the quality of education provided at each school. At the same time, in a process which continues well into the 2010s, the range of schools on offer was increased: grant maintained schools, specialist schools, academies and now free schools are examples of the diversity of provision begun in the late 1980s. The introduction of market forces and competition, through the changes to both the supply (school diversity) and demand (parental choice) sides of the equation, was intended to raise standards.

The marketisation of education in the UK has been much discussed and criticised (Ball, 1993; Ball, 2008a), as have similar systems worldwide (Apple, 2001; Lauder and Hughes, 1999). In the UK, research suggested several negative consequences, and there were doubts about whether parents actually wanted to choose a school:

Ideological belief that all parents desired and would benefit from choice between schools was not borne out by research, which into the 1990s had indicated that apart from those parents seeking private or selective schools, what most parents wanted was a good local comprehensive school, well resourced and staffed and offering equality of treatment of all children

(Tomlinson, 2005, p. 54) 
This research revealed a flaw in the logic of the market in schooling: parents did not necessarily want to choose, because a 'good choice' meant all having the same thing a good quality education for their child. In this way, the rationality of parents as the subjects of policy was brought into doubt. Furthermore, since not all children could go to the top-performing school, the system encouraged parents to be tactical and even dishonest in order to secure a place for their child at a chosen school. Instead of empowering parents, the choice system 'encouraged parents to be 'vigilantes' and complainants rather than partners in schooling' (Tomlinson, 2005, p. 54).

Moreover, research conducted in the 1990s suggested that the way in which parents choose schools reinforces and exacerbates social divisions (Gewirtz, Ball and Bowe, 1995). This research demonstrated that parents do not choose in the same way, given the same range of choice and the same information. In particular, 'disconnected' choosers were reluctant to get involved in the choice process, and usually opted for the nearest school without taking into account league table data. Indeed, more recent analysis continues to show that significant differences persist in the extent to which affluent and poorer families exercise choice (Burgess et al, 2006; Burgess, Propper and Wilson, 2007), such that the choice system in place has resulted in increased social segregation, with working class students more likely to be in lower-attaining schools (Lupton, 2006). These findings were further reinforced by research from other education systems around the world which indicated that markets in education increased social segregation (Angel Alegre and Ferrer, 2010).

In the 2000s, Labour governments added to the diversification of schools, and continued to expound the advantages of allowing parents to choose. However, instead of simply allowing the market to operate, and those 'flawed consumers' (Bauman, 2005) who made 'bad' educational choices to suffer, the government recognised this failure to produce the neoliberal rational choosing subject, and legislated to change the situation. As Exley's (2009; 2012) work on this area notes, changes were made to both to the supply side of choice, through the introduction of admissions codes, and more importantly for our argument, to the demand side, through attempts to influence how parents choose. The latter was achieved though the introduction of a network of 'Choice Advisers' following the 2006 Education and Inspections Act, which put a duty on local authorities to provide advice and assistance to parents when they express a preference for a school. These Choice Advisers provide an example of the revision of rationality we focus on here. From 2006, the Labour government spent $£ 12$ million on the Choice 
Advice network (Exley, 2009). These independent advisers offer advice to parents through various channels (including face to face meetings, phonecalls and text messages). Their aim, in the words of one local authority website, is 'to help and support families to make the best and most realistic choice of school for their child' (Camden, 2011). These Choice Advisers were intended to compensate for the inequalities which result from a choice system, as shown by the weighting of funding to disadvantaged areas.

The introduction of 'Choice Advice' was based on an implicit acceptance of the failure of school choice systems to produce optimum outcomes for all. The Schools Minister, Jim Knight, explained:

A wide variety of information is already available to help parents make decisions but we know that not all parents are accessing this and many still find it difficult to navigate the admissions system (BBC News, 2006)

The policy combines the basics of neoliberal ideology with an attempt to counteract the negative impact of people choosing in ways deemed to be 'irrational': in Exley's words, 'leaving enshrined the basic individualist right of consumers to make free choices [...] but also attempting to correct for market failures and to 'make choice fairer' (Exley, 2009, p. 250). As the documentation related to Choice Advice emphasises, the advisers do not make any decisions about school for parents; they simply provide information. However, this is particular information, at a particular time and socially through an adviser; thus the process by which the chooser receives information is changed. This process, we would argue, has similarities with the kind of 'choice architecture' espoused by the authors of Nudge and others in behavioural economics. By providing advice and information on schools to parents in this form, the government provides a structure for their choices, in a similar way to the dietary information provided to help people make healthier food choices in a supermarket or restaurant. Providing the right choice architecture is important because, in the language of Nudge, a choice of school is a decision with a low level of feedback (like choosing what to eat) because the impact is not known for some time, perhaps years. Thus people need advice in order to help them make better, 'informed choices'.

However, the implication of the provision of Choice Advice targeted towards disadvantaged areas was that not all parents needed to be guided towards better choices; only certain groups of parents were less well equipped to make the 'right' choices. The Labour government chose to intervene to ensure the system did not further exacerbate 
social inequalities, but in doing so, implied that these parents in particular were 'bad choosers'. These parents' norms, their priorities and ways of choosing, are deemed unacceptable, and so a new person (the Choice Adviser) is inserted into their social network; this is similar to the description of the importance of the Messenger in the more recent Mindspace report (Dolan et al, 2010). The blame for the failure of the choice system as a fair allocation mechanism is thus placed with these parents, rather than with any flaw in the use of markets in education. Nonetheless, the ideal of rational agents making choices to the benefit of all is revised: some need to be helped to make rational choices, 'nudged' in the right direction. Thus the revision to this policy, while changing a fundamental principle of markets in education (that consumer choice is paramount), obscures the failure of policy to produce rational subjects, and avoids any challenge to the policy overall.

Furthermore, this example demonstrates the markedly different focus of policy within this new rationality: gone is the impact of policy on the subject (the encouragement of parents to value and pursue 'good choices' for their children), to be replaced by fixed subjects which we can assume we understand through (in this case) their social position. Choice is exteriorised: there is no attempt to change these subjects internally, but instead the impact is on choice and behaviour (using information on schools more, listening to advice) in order to produce the 'right' outcomes.

\section{Revised rationality: the youth opportunity card and positive activities}

We have argued in this article that behaviourist discourses have been incorporated into policy not to supplant but rather to allow for the continuation of the neoliberal policy regime. With this in mind, youth services constitute an interesting alternative example of this incorporation to school choice policy. While youth services have also been subject to neoliberal policy reform, the timing of those reforms differs markedly[3]. Our aim here, then, is to use this particular timing of reforms to illustrate this notion: that is, to describe the situation in youth services where neoliberal reform was followed much more quickly by the incorporation of policy discourses asserting the limits of the rationality of the policy subject, in an almost simultaneous, perhaps even mutual, process.

While New Labour's time in office is notable for an increased emphasis in youth services on 'targeted' interventions for young people at risk of or already in trouble (Spence, Devanney and Noonan, 2006), here we wish to look at reforms of 
universal, open-access youth and leisure services outlined in Youth Matters (DfES, 2005) and Aiming High (DCSF, 2007) to illustrate how moves were made simultaneously to position young people as rationally choosing consumers of services, and to change the choices available to them in important ways. Specifically, we consider the proposed 'Opportunity Card' (DfES, 2005; DfES, 2006b) and the concomitant structuring of the choice environment through 'positive activities'.

Open-access leisure provision for young people outside of school has historically been a significant element of youth services (Davies, 1999b). In Youth Matters the then Labour government reiterated its intention to promote and develop such an offer for all young people, alongside volunteering opportunities, provision of targeted support for young people in need, and access to relevant information, advice and guidance (DfES, 2005, p. 63), framing this intention with the policy aim of ensuring that all young people achieved the five Every Child Matters outcomes (DfES, 2005, p. 27).

The New Labour youth service policy ensemble had already seen the emergence of young people figured as rational individual subjects with 'voice' and 'choice'. Within this ensemble, Youth Matters is distinctive in its commitment to put 'buying power directly in the hand of young people themselves' (DfES, 2005, p. 25) through two initiatives: i) a new local authority revenue fund - the 'Opportunity Fund' - in which young people would have some representation in decision making; and ii) an 'Opportunity Card' which would give individual young people money that would subsidise or offer discounts on activities from accredited providers. The latter measure in particular positions young people as direct consumers of youth service leisure provision, and utilises the market as the appropriate mechanism to ensure more young people get involved in youth service provision in their leisure time, and have their preferences reflected in the supply of that provision:

Putting spending power in the hands of young people will make sports and constructive activities more affordable. It will also mean that young people's choices influence directly what is available - ensuring that the activities available are those that young people want and will use. (DfES, 2005, p. 28)

Disadvantaged young people were to receive an enhancement of their buying power through 'top-ups' to their cards, thus removing financial barriers to participation and ensuring the market would be responsive to their needs and not only those able to leverage the economic resources of their more wealthy families. 
This move clearly positions young people as rational choosers whose expressions of preference are a crucial mechanism to drive up the quality of provision of universal youth services. However, just prior to the publication to Youth Matters, an influential report was published that indicated important limitations of both certain youth leisure provision and the choice making of particular categories of young people with respect that leisure provision. Feinstein et al.(Feinstein, Bynner and Duckworth, 2005) argued in the report, cited twice within Youth Matters, that the choosing behaviours of a young person 'from a low socio-economic status and lowincome family, and with a poor school record' were distinct from young people 'identified with higher socio-economic status families...in tune with schooling' (Feinstein, Bynner and Duckworth, 2005, p. 10): the former were attracted to the unstructured environments of youth clubs, while the latter tended to choose environments with a 'general focus on structured, joint activities towards a common goal' (Feinstein, Bynner and Duckworth, 2005, p. 22) such as sports groups, uniformed clubs (for example the Scouts and Guides), and church- and school-based leisure activities. Further, associations were found between participation in these differing 'leisure contexts' and adult outcomes organised according to the five ECM outcomes. In short, young people at risk of social exclusion by choosing to attend open-access youth clubs were found to be 'either exacerbating their level of risk or seeking out contexts that did little to offset the apparent risk' (Feinstein, Bynner and Duckworth, 2005, p. 17).

Though published prior to Nudge, Feinstein et al describe a failure of rationality that can be understood in its terms. Young people were said to be making selections influenced by peer group and that association with their peer group explained 'a large part of the negative effects of unstructured youth settings' (Feinstein, Bynner and Duckworth, 2005, p. 22), a claim closely echoed in the discussion in Nudge of 'peer pressure' and the 'power of social nudges' with respect to outcomes such as teenage pregnancy, educational outcomes and obesity (Thaler and Sunstein, 2009, p. 58-59). Further, the effect of participation in different leisure activities on outcomes is another clear example of a choice system within a long-term process (personal development) with limited immediate feedback (Thaler and Sunstein, 2009, p. 82-83). It is significant therefore that the empowerment of the young person as a consumer through the proposed 'Opportunity Card', is accompanied by a recasting of the choices young people can make regarding their 
leisure time through the introduction of the term 'positive activities'. Positive activities, referred to throughout Youth Matters and Aiming High, is a reconceptualisation of leisure based youth services that relates them directly to the achievement of Every Child Matters outcomes (DfES, 2005, p. 20). Aiming High, citing an updated research report reiterating and extending the findings of the previous one (Feinstein and Robson, 2007), emphasises the centrality of the notion of 'structure' to the achievement of ECM outcomes, and thus to the definition of a 'positive activity':

New evidence confirms that it is the level of 'structure' in the delivery of activities which is most important...Young people who had joined clubs offering highly structured activities did better in later life (DCSF, 2007, pp. 21-22)

Positive activities became the basis of a new statutory requirement placed on local authorities (DfES, 2006a) for the provision of educational and recreational leisure opportunities and facilities. Moreover, this reformation was in response to the nonoptimal choosing of the young person subject.

...the real challenge...in working with disadvantaged young people is to introduce structure and greater organisation and supervision into the unstructured provision to which they are naturally more likely to be drawn. (DCSF, 2007, p. 22).

Positive activities might thus be seen then as a piece of 'choice architecture' conducted even as the figure of the young person as a consumer, a rational chooser, was being extended and embedded in youth service policy. In this move, 'universal youth services' came to signify a choice environment in which the young person was both figured as a rational chooser, and as the location of a 'natural' irrationality which required the re-structuring and constraint of that choice environment. Though the Opportunity Card proposed by Youth Matters was scrapped before it left the pilot stage (BBC News, 2007), 'choice' and the language of choice has been maintained. Thus we have a complex picture of policy that both seeks to systematically produce young people as (rational) choosers, and to manipulate and limit the context of their 'choosing' for political ends (however legitimate those ends may be). Crucially, these measures are not in disruptive, but supportive relation to each other, requiring that discourses of rational consumer of neoliberalism and a discourse of irrationality are simultaneously maintained. 


\section{Behavioural Economics and the Coalition government}

Although much of the policy we have focused on here dates from the previous Labour governments, it has been the Conservative-Liberal Democrat coalition government from 2010 onwards that has made explicit use of behavioural economics in policy. The Behavioural Insight Team ( known as the 'Nudge Unit'), whose aim is to find 'intelligent ways to encourage, support and enable people to make better choices for themselves' (Cabinet Office, 2011, p. 3), exemplifies this construction of these approaches as new and transformative. The use of behavioural economics by the Conservative-Liberal Democrat government also reflects a wider tendency for politicians to take up particular forms of 'academic' research, in this case in the form of accessible (and widely read) texts for their own adaptation into policy; the use of insights from the book 'The Spirit Level' (Wilkinson and Pickett, 2009) by various politicians in the late 2000s is another example. The use of the language of behavioural economics is convenient for the Conservative-Liberal Democrat government as it gives the impression of adapting new science to old problems (and saving money at the same time). However, we would argue that the adoption of these ideas is only possible because the idea of shaping people's choices already exists in policy; for example, in the use of Choice Advisers. The relative familiarity of some of these moves then, makes these policy shifts seem acceptable, while at the same time the language of Nudge makes them appear innovative. Although we can see the use of behavioural economics by the UK government as a temporary convenience, this does not reduce its significance. We would argue that policy trends matter in that they are a way of making sense of existing issues, often with a new language. The use of Nudge makes the government appear at the vanguard of social policy, proposing new ways to deal with familiar problems.

It is also important not to overstate the coherence or linearity of policy shifts such as these. We have already noted that behavioural economics is only one of several such influences reshaping how the concept of rationality in policy can operate. These other influential contingent knowledges make alternative possibilities available to policy makers in the face of different problems. However, even retaining a narrower focus on 'nudges' coherence cannot be assumed, as we see with the example of social mobility below. Although it might be presented as a worked-out theory in books like Nudge, behavioural economics in policy leaves much unexplained and many questions unanswered; not least, how the professed aim of 'making it easier for citizens to make 
better choices for themselves' (Cabinet Office, 2011, p. 4) is to be assessed or evaluated.

It is worth noting here that the Behavioural Insight Team (the 'Nudge Unit') has been met with some scepticism; indeed, one commentator called it the 'wackiest and most vogueish corner of government' (Goldacre, 2011). In particular there has been criticism of its over-extrapolation from small-scale research (Goldacre, 2011). Nonetheless, its first annual report (Cabinet Office, 2011) makes bold claims as to the impact and potential of behavioural insights as new policy tools. These mainly relate to areas of health, the environment (energy use being a major impact) and paying tax. There are some references to education and parenting which suggest that these are areas of focus in the future, but there is a dearth of detail on policy changes. For example, under the title 'Social Mobility', the report notes:

A key objective is to encourage young people to consider a range of careers and to aim high in considering further and higher education options. Young people from disadvantaged backgrounds tend to have less awareness of professional career options, which can adversely affect their subject choices and focus. They subsequently tend to under-apply to leading universities, even if their grades are good enough. (Cabinet Office, 2011, p. 22)

There is no indication in the report, however, of how this information will be provided to young people, or how they will be encouraged to apply to university (and furthermore, the removal of funding for the AimHigher programme, which aimed to foster high expectations among students seen as less likely to go to university, suggests that government policy is currently working in the opposite direction). Nonetheless, the identification of this issue as an area for the Behavioural Insight Team suggests that the idea of providing more information to particular groups, seen in the use of Choice Advisers and youth policy, is now explicitly linked to the use of behavioural economics.

Parenting too comes under the gaze of the Behavioural Insight Team ; the report notes that:

Parenting is a key driver of many child outcomes and is a learned skill - it is what parents do, not who they are, that matters. There is robust evidence that parenting interventions can strengthen parenting skills. (Cabinet Office, 2011, p. 22 our emphasis)

In this comment we again see the focus on actions, choices and behaviour, rather than on changing the subject itself. If the subject fails to behave appropriately - in this case by engaging in 'good parenting' - then the government needs to intervene to change 
that behaviour, not to change the subject. It remains to be seen whether further education policy from the Coalition government will be influenced by behavioural economics; however, it seems likely because, as we have demonstrated with previous examples, the model of the rational subject of policy has already been revised. It is also worth noting here that behavioural economics is not the only 'new' field that has been applied to policy making in recent years: simultaneously, neuroscience and network theory have similarly been adopted by policy makers. For reasons of space, we are unable to detail the influence of these fields here; however, we regard these as comparably significant developments regarding the figuring of subjects in policy.

\section{The significance of this revision}

So, why does this revised notion of rationality within policy matter? We argue that the identification and discussion of this shift matters because we need a critical examination of the new directions policy is taking us in, and because we need to be aware of where this journey might take us next. Is it necessary to delve so deep in our criticality? After all, the dismantling of the central tenets of neoliberalism, if this even represents such a significant move, might be welcomed by many in education. We would argue, however, that the replacement of a model of a rational chooser with one so flawed that he needs 'nudging' in a particular and externally defined 'right' direction, is significant. Who is influenced by 'choice architecture' and told their choices are wrong? And what are consequences for those that refuse to be 'nudged' in whatever way the government deems to be 'better'? This revision is not a purely abstract phenomenon; it has real-life effects on people and their every-day lives, in education and beyond - how they choose a school, how they make financial decisions, how they decide what to eat. Our concern here is not the effectiveness of these policies, but the opening up of new possibilities for policy. As sociologists of education, we are aware that in this time of a supposed 'crisis', we need to sharpen our critical tools in our analysis of neoliberalism.

\section{Conclusion}

There are five facets of this revision of rationality which we summarise in this conclusion: changes to what is happening (the logic of policy making); who it happens to (the subjects of policy) and who makes policy; how it happens (the means of policy making or policy technologies); and why it happens (the ends of policy making). Together, we see these elements as a revision of a rational subjectivity in policy-making which has dominated in the neoliberal era. 
The use of behavioural economics in policy-making has altered the logic of policy, as the acceptance of the irrationality of the subject leads to a new balance between two opposing logics of freedom and control. As epitomised by the Nudge authors' use of the term 'liberal paternalism', this new logic seeks to combine freedom of choice with the control of that choice, a paternalist obligation to help individuals make better decisions. This control is necessary to solve the problem of our 'failed' irrationality, but it sits alongside the priority of freedom to choose. This project, as we discuss in our final point, allows much to stay the same while fundamental principles are altered.

This revision simultaneously changes the subject of policy; the ideal of the rational chooser who objectively selects the best option, leading to the optimum outcomes for all, is altered completely. The principles of choice, however, are not abandoned: choices must still be made, but within a framework constructed to compensate for the irrationality of the subject. Thus the site of policy intervention changes: there is a recognition that the subject itself (and its brain in particular) cannot be changed from its irrational state, and thus it is the choice itself that must be altered. Choice becomes exteriorised and thus flexible and malleable. Our example of Choice Advisers epitomises this shift from the reification of choice to an attempt to reconfigure patterns of choosing.

In turn, the role and potential of the policy-maker is also revised: he becomes the choice architect, responsible for framing and influencing our choices rather than for making neoliberal consumer-subjects. Within behavioural economics, there is great potential for policy-led change: in health, in energy use, and as we have suggested, in education and youth services. The example we provided of changes to youth service policy shows how policy-makers can become arbiters of what are useful, 'positive' and worthwhile activities.

The means of policy-making - the policy technologies at these policy-makers' disposal - are also altered, in a sense supplemented, by this new conception of rationality. The policy maker as choice architect has an alternative range of tools to foster social change: framing decisions, choosing default options and 'nudging' the subjects of policy into 'good choices'. As the Behavioural Insight Unit's report indicates, these are seen as powerful new policy technologies capable of radically altering how people live their lives. 
Finally, we argue that the ends of policy are changed as part of this revision: the aim of policy is no longer to produce the rational choosing subject, but to frame and inform the choices that the irrational subject makes. This is a fundamental shift in the ends of policy making, and in turn an implicit recognition of the failures of neoliberalism.

We see this revision as part of a survival strategy for neoliberalism in policy, a jettisoning of a vital principle in order to allow the entire project to continue. We are by no means suggesting that neoliberalism as a concept has been abandoned, nor is it even in crisis: this is a revision, a smoothing over of one of the flaws of neoliberalism with a supposed new discipline of behavioural economics or liberal paternalism. Nonetheless, this revision still has consequences and potentially a significant impact on education policy, which we need to examine as its influence grows.

Notes:

1. 'Behavioural sciences' is the term preferred in the Institute for Government Report Mindspace (Dolan et al, 2010) that draws on research from the fields of psychology and behavioural economics for the development of new policy technologies for the influence of the behaviour of individual subjects of policy. In this sense it is broadly equivalent to 'behavioural economics'.

2. Our use of the term 'changing the game' references Lyotard's (Lyotard, 1984) use of the metaphor in his description of the central importance of the performative in 'language games' that compose the 'social bond' in post-industrial society (Lyotard, 1984, pp. 9-11), and in turn, Ball's influential development of the concept of performativity as a technology of neoliberal education policy (Ball, 2003).

3. Though, as Davies points out, the management of statutory youth work had been influenced by neoliberal reforms of local authorities and of other public services, and the changing 'culture' of public service provision that had accompanied it (Davies, 2012).

4. The Thompson Report (DES, 1982) was the only major review of the youth service during this period (Davies, 1999a)

5. The voluntary sector is estimated to now be the largest provider of youth services in England (House of Commons Education Committee, 2011, p. 38)

6. For example, the paper on 'Adolescent Brain Development' (DfE, 2011) published by the Department for Education as part of the Conservative-Liberal Democrat government's Positive for Youth policy consultation process draws mostly on neuroscience and cognitive psychology to explain educational, health and social problems associated with young people, and then draws a series of 'policy implications' from this basis.

\section{References:}


Angel Alegre, M. and Ferrer, G. (2010). 'School regimes and education equity: some insights based on PISA 2006'. British Educational Research Journal, 36 (3), 433-461.

Apple, M. W. (2001). Educating the "right" way: markets, standards, God, and inequality. London: RoutledgeFalmer.

Apple, M. W. (2003). 'Competition, Knowledge, and the Loss of Educational Vision'. Philosophy of Music Education Review, 11 (1), 3-22.

Ball, S. (1993). 'Education Markets, Choice and Social Class: The Market as a Class Strategy in the UK and the USA'. British Journal of Sociology of Education, 14 (1), 3-19.

Ball, S. (2007). Education plc : understanding private sector participation in public sector education. London: Routledge.

Ball, S. (2008a). The education debate. Bristol: Policy Press.

Ball, S. J. (2001). 'Performativities and Fabrications in the Education Economy: Towards the Performative Society'. In H. Lauder, P. Brown, J.-A. Dillabough and A. H. Halsey (Eds), Education, Globalization and Social Change (pp. 692701). Oxford: Oxford University Press.

Ball, S. J. (2003). 'The teachers soul and the terrors of performativity'. Journal of Education Policy, 18 (2), 215-228.

Ball, S. J. (2008b). The Education Debate. Bristol: The Policy Press.

Bauman, Z. (2005). Work, consumerism and the new poor. (2nd Ed.). Maidenhead: Open University Press.

BBC News. (2006). Help for parents choosing school. [Online]. Available at: http://news.bbc.co.uk/1/hi/education/5063238.stm. [Last accessed 30 May 2012].

BBC News. (2007). Ministers scrap youth bonus card. [Online]. Available at: http://news.bbc.co.uk/1/hi/education/6409327.stm. [Last accessed 12 December 2011].

Birch, K. and Mykhnenko, V. (2010). The rise and fall of neoliberalism: the collapse of an economic order?: Zed Books.

Bowe, R., Ball, S. J. and Gold, A. (1992). Reforming education and changing schools: Case Studies in Policy Sociology. London: Routledge.

Bunyan, P. and Ord, J. (2012). 'The neoliberal policy context of youth work management'. In J. Ord (Ed.), Critical Issues in Youth Work Management (pp. 19-29). London: Routledge.

Burgess, S. (2012). Message from the Director. [Online]. Available at: http://www.bristol.ac.uk/cubec/digest/digestfeb12.pdf. [Last accessed 30 May 2012].

Burgess, S., Briggs, A., McConnell, B. and Slater, H. (2006). School Choice in England: Backgroun Facts. Bristol: Centre for Market and Public Organisation.

Burgess, S., Propper, C. and Wilson, D. (2007). 'The Impact of School Choice in England'. Policy Studies, 28 (2), 129-143.

Cabinet Office. (2011). Behavioural Insights Team: Annual update 2010-11. London: Cabinet Office.

Camden. (2011). How can a choice advisor help? [Online]. Available at: http://www.camden.gov.uk/ccm/content/education/schools/choice-adviceservice/how-can-a-choice-adviserhelp.en;jsessionid=48B4EE0AB28A586D29F7719603FE3A8F.node2. [Last accessed 6 October 2011]. 
Chakrabortty, A. (2010). Cameron's hijacking of Nudge theory is a classic example of how big ideas get corrupted. [Online]. Available at: http://www.guardian.co.uk/commentisfree/2010/dec/07/david-cameronhijacked-nudge-theory?intcmp=239. [Last accessed 16 December 2011].

Crouch, C. (2011). The Strange Non-death of Neo-liberalism: John Wiley \& Sons.

Curtis, P. (2011). 'Nudge unit' not guaranteed to work, says Oliver Letwin. [Online]. Available at: http://www.guardian.co.uk/politics/2011/feb/20/nudge-unitoliver-letwin. [Last accessed 16 December 2011].

Davies, B. (1999a). From Thatcherism to New Labour: a history of the Youth Service in England Volume II: 1979-1999. Leicester: Youth Work Press.

Davies, B. (1999b). From Voluntaryism to Welfare State: A History of the Youth Service in England Volume 1 1939-1979. Leicester: National Youth Agency.

Davies, B. (2012). 'From advice to management: the arrival of the youth workers' accountability'. In J. Ord (Ed.), Critical Issues in Youth Work Management (pp. 7-18). London: Routledge.

Davies, B. and Merton, B. (2009). 'Squaring the Circle? The State of Youth Work in Some Children and Young People's Services'. Youth \& Policy, (103), 5-24.

Dawnay, E. and Shah, H. (2005). Behavioural economics: seven principles for policymakers. London: New Economics Foundation.

DCSF. (2007). Aiming high for young people: a ten year strategy for positive activities. London: Department for Children Schools and Families.

DES. (1982). Experience and Participation. Review Group on the Youth Service in England. London: HMSO.

DfE. (2011). Adolescent Brain Development. [Online]. Available at: http://www.education.gov.uk/childrenandyoungpeople/youngpeople/positive\% 20for\%20youth/b00200953/collaboration/positive-for-youth-discussionpapers.

DfEE. (2001). Transforming Youth Work: Developing youth work for young people. Nottingham: DfEE Publications.

DfES. (2002). Transforming Youth Work: resourcing excellent youth services. London: Department for Education and Skills.

DfES. (2005). Youth Matters. London: Department for Education and Skills.

DfES. (2006a). 'Statutory Guidance on Positive Activities'. [Online]. Available at: http://www.education.gov.uk/consultations/downloadableDocs/Statutory\%20 Guidance\%20on\%20Postive\%20Activities.doc. [Last accessed 30 May 2012].

DfES. (2006b). Youth Matters: Next Steps. London: DfES Publications.

Dolan, P., Hallsworth, M., Halpern, D., King, D. and Vlaev, I. (2010). Mindspace: Influencing behaviour through public policy. London: Institute for Government.

Duménil, G. and Lévy, D. (2011). The Crisis of Neoliberalism: Harvard University Press.

Exley, S. (2009). 'Emerging discourses within the English 'choice advice' policy network'. London Review of Education, 7 (3), 249-260.

Exley, S. (2012). 'Making working-class parents think more like middle-class parents: Choice Advisers in English education'. Journal of Education Policy, iFirst July 2012

Feinstein, L., Bynner, J. and Duckworth, K. (2005). Leisure Contexts in Adolescence and their Effects on Adult Outcomes. London: Center for Research on the Wider Benefits of Learning. 
Feinstein, L. and Robson, K. (2007). Leisure Contexts in Adolescence and their Associations with Adult Outcomes: A More Complete Picture. London: Centre for Research on the Wider Benefits of Learning.

Foucault, M. (1981). The Will to Knowledge. London: Penguin.

Gamble, A. (2010). 'After the Crash'. Journal of Education Policy, 25 (6), 703-708.

Gewirtz, S., Ball, S. and Bowe, R. (1995). Markets, choice and equity in education. Buckingham: Oup.

Goldacre, B. (2011). Effective things can come from silly places, . [Online]. Available at: $\quad$ http://www.guardian.co.uk/commentisfree/2011/jul/08/bad-scienceeffective-things-silly-places. [Last accessed 16 December 2011].

Green, A. (1993). 'Magnet schools, choice and the politics of policy borrowing'. Oxford Studies in Comparative Education, 3, 83-104.

House of Commons Education Committee. (2011). Services for young people: Third Report of Session 2010-12 Volume 1. London: The Stationery Office Limited.

Jeffs, T. and Smith, M. K. (Eds) (2010), Youth Work Practice. Basingstoke: Palgrave Macmillan.

Jessop, B. (2002). The future of the capitalist state. Cambridge: Polity Press.

Jones, K. (2010). 'Crisis, what crisis?'. Journal of Education Policy, 25 (6), 793-798.

Lauder, H. and Hughes, D. (1999). Trading in futures: why markets in education don't work. Buckingham: Open University Press.

Le Grand, J. (2001). 'Quasi-Markets and Social Policy'. In S. P. Osborne (Ed.), Public Management: Critical Perspectives (Vol. 2, pp. 9-22). London: Routledge.

Levin, H. M. and Belfield, C. R. (2003). 'The Marketplace in Education'. In H. Lauder, P. Brown, J.-A. Dillabough and A. H. Halsey (Eds), Education, Globalization and Social Change (pp. 620-641). Oxford: Oxford University Press.

Lupton, R. (2006). 'How does Place Affect Education'. In S. Delorenzi (Ed.), Going Places: Neighbourhood, Ethnicity and Social Mobility. London: Institute of Public Policy Research.

Lyotard, J.-F. (1984). The Postmodern Condition: A Report on Knowledge. Manchester: Manchester University Press.

Olssen, M. (1996). 'In defence of the welfare state and publicly provided education: a New Zealand perspective'. Journal of Education Policy, 11 (3), 337-362.

Ong, A. (2006). Neoliberalism As Exception: Mutations in Citizenship And Sovereignty: Duke University Press.

Peck, J. and Tickell, A. (2002). 'Neoliberalizing Space'. Antipode, 34 (3), 380-404.

Rose, N. S. (1996). 'Governing "advanced" liberal democracies'. In A. Barry, T. Osborne and N. S. Rose (Eds), Foucault and political reason: liberalism, neoliberalism, and rationalities of government: University of Chicago Press.

Rowson, J. (2011). Transforming Behaviour Change: Beyond nudge and neuromania. London: RSA.

Smith, M. K. (2002). Transforming youth work - resourcing excellent youth services. A critique. [Online]. Available at: http://www.infed.org/youthwork/transforming_youth_work_2.htm. [Last accessed 25 June 2010].

Spence, J., Devanney, C. and Noonan, K. (2006). Youth Work: Voices of Practice A research report by Durham University and Weston Spirit. Leicester: Natonal Youth Agency.

Thaler, R. H. and Sunstein, C. R. (2009). Nudge: Improving decisions about health, wealth and happiness. London: Penguin. 
Tomlinson, S. (2005). Education in a post-welfare society. (2nd Ed.). Maidenhead: Open University Press.

Tyler, R. (2011). Whitehall won't be 'nudged', finds National Audit Office. [Online]. Available

at: http://www.telegraph.co.uk/finance/economics/8328873/Whitehall-wont-benudged-finds-National-Audit-Office.html. [Last accessed 16 December 2011].

Vincent, C. (1994). 'The market forces? the effect of local management of schools on special educational needs provision. '. British Educational Research Journal, 20 (3), 261-277.

Walkerdine, V. (2003). 'Reclassifying Upward Mobility: femininity and the neo-liberal subject'. Gender and Education, 15 (3), 237 - 248.

West, A. and Pennell, H. (2002). 'How New is New Labour? The Quasi-Market and English Schools 1997-2001'. British Journal of Educational Studies, 50 (2), 206-224.

Whitty, G. (1997). 'Creating quasi-markets in education : a review of recent research on parental choice and school autonomy in three countries'. In M. W. Apple (Ed.), Review of research in education (Vol. 22, pp. 3-47). Washington, D.C.: American Educational Research Association.

Wilkinson, R. G. and Pickett, K. (2009). The Spirit Level: why more equal societies almost always do better. London: Penguin.

Wintour, P. (2010). David Cameron's 'nudge unit' aims to improve economic behaviour.

[Online].

Available

at:

http://www.guardian.co.uk/society/2010/sep/09/cameron-nudge-uniteconomic-behaviour. [Last accessed 16 December 2011]. 